\title{
TURKEY AS A REGIONAL POWER: NEO-OTTOMANISM IN ACTION
}

Over the past decade Prime Minister Rejep Tayyip Erdoğan's government and his AKP (Justice and Development Party) have been successful in undermining Mustafa Kemal's legacy and the character of the state founded upon that legacy. What remained, until the 2010 referendum on constitutional amendments, was an increasingly empty shell of constitutional secularism. That shell was nevertheless an obstacle to the formal grounding of the new legitimacy in Islam at home and neo-Ottomanism abroad. Erdoğan and his team were determined to remove such vestiges, however, and on September 12, 2010, they succeeded. On that day Turkey's voters approved, by a large margin, a 26-article package which ended the role of the Army as the guardian of secularism. In 2011 Erdoğan was duly reelected with a substantial majority for a third term.

Davutoglu's Strategic Depth - What has become known as Turkey's neo-Ottoman strategy became prominent with the appointment of Ahmet Davutoglu as foreign minister in 2009. As Erdogan's long-term foreign policy advisor, he advocated diversifying Turkey's geopolitical options by createing Turkish zones of influence in the Balkans, the Caucasus, Central Asia, and the Middle East. On the day of his appointment Davutoglu asserted that Turkey's influence in "its region" will continue to grow: Turkey had an "order-instituting role" in the Middle East, the Balkans and the Caucasus, he declared, quite apart from its links with the West.

In Davutoglu's own words, Turkish foreign policy has evolved from being "crisis-oriented" to being based on "vision": "Turkey is no longer a country which only reacts to crises, but notices the crises before their emergence and intervenes in the crises effectively, and gives shape to the order of its surrounding region." He asserted that Turkey had a "responsibility to help stability towards the countries and peoples of the regions which once had

\footnotetext{
* Историчар, политиколог (аналитичар међународних односа, гео-политичар итд.), уредник међународне рубрике часописа „Cronicl“, професор по позиву Факултета политичких наука у Бањој Луци.
} 
links with Turkey" - thus referring to the Ottoman era, in a manner unimaginable only a decade ago: "Beyond representing the 70 million people of Turkey, we have a historic debt to those lands where there are Turks or which was related to our land in the past. We have to repay this debt in the best way."

This strategy was based on the assumption that growing Turkish clout in the old Ottoman lands - a region in which the EU has vital energy and political interests - could prompt President Sarkozy and Chancellor Merkel to drop their objections to Turkey's EU membership. If on the other hand the EU closes its door to enlargement - as now seems imminent - then Turkey's huge autonomous sphere of influence in the old Ottoman domain would be developed into a major and potentially hostile counter-bloc to the West.

Prime Minister Erdogan is no longer as eager as before to minimize or deny his Islamic roots, but his old assurances to the contrary — long belied by his actions - are still being recycled in Washington and treated as reality. This reflects the propensity of the Obama administration, just like its predecessors, to cherish illusions about the nature and ambitions of America's regional "allies," such as Saudi Arabia and Pakistan. The implicit assumption in the U.S. foreign policy community - that Turkey would remain "proWestern," come what may - should have been reassessed years ago. Since the AKP came to power the Army has been neutered, confirming the old warning of the Turkish top bras that "democratization" would mean Islamization. To the dismay of its Westernized secular elite, Turkey has reasserted its Ottoman and Muslim legacy with a vengeance.

We are witnessing the end of a process that could be predicted with precision. Nine years ago I wrote in Chronicles (April 2003) that the Bush Administration was mistaken to pretend that Turkey was "a truly indispensable nation" - as a senior U.S. Administration official, Paul Wolfowitz, called it at the time:

In his pitch to the West Mr. Erdoğan is unsurprisingly eager to minimize his party's Islamic connections by stressing his "secular" and "conservative" credentials. His assurances were keenly accepted in Washington... The escalating crisis of Turkey's political system over the past decade reflected a deeper malaise, the loss of confidence of the old Kemalist elite. The implicit assumption in Washington-that Turkey would remain "secular" and "pro-Western," come what may - should have been reassessed after the Army intervened to remove the previous pro-Islamic government in 1997. Since then many voices have warned that "democratization" would mean Islamization, and that America needed alternative scenarios and regional strategies. 
Nine years later this assessment has been proven right. Erdoğan and his team claim that the marginalization of the Army heralds the country's democratization. Practicing the Islamic art of taqiyya in its purest form, foreign minister Davutoğlu claims that the AKP reversal of Kemalism was all about advancing civil rights and Western-style liberties, that it reflects "the Turkish nation's will to live in a freer and more democratic environment in compliance with European Union standards." It is "an important turning point for democracy in Turkey," he says, and "a result of the Turkish nation's interest in the reform process carried out in light of universal and European norms.” President Abdullah Gül claims that Turkey can now have a "great and unbelievably positive effect" on the Middle East. Ahmet Davutoglu adds, "If the world is on fire, Turkey is the firefighter... assuming the leading role for stability in the Middle East."

Securalists' Demise - The terminal loss of confidence of the old Kemalist elite was swift and now seems irrversible. The fruits of AKP rule invoke the memory of the late Necmettin Erbakan, who announced many years ago that "Turkey is going to change its regime towards fundamentalism - the debate is whether it is going to be with blood or without." The change of the Turkish state and society, of its ethos and institutional culture, is profound. The secularist elites see it happening, "but they are gripped by panic, paralyzed, unable to act, living just for today," Claire Berlinski, an Americanborn writer and journalist who has lived in Istanbul for years, told me on my last visit to Turkey in January 2011. She compared the atmosphere in the city to the last days of the Weimar Repuiblic in Berlin: the writing is on the wall.

The lack of support from Washington has been a factor in demoralizing the Kemalist establishment, but more important perhaps was the manner in which Erdoğan and the AKP had succeeded in obtaining the compliance of the secularist elite in the crucial early years of their mandate. Turkey's activist foreign policy had seduced them with the vision of an autonomous sphere of Turkish influence in the old Ottoman domains in the Middle East, the Caucasus, and the Balkans. It has enabled the Islamists to co-opt into the project many senior civil servants, diplomats and generals who are not sympathetic to the ideological assumptions of the neo-Ottoman paradigm, but who were ready and willing to support its "quantitative" aspects. They subscribed to the ostensibly traditional, nationalist components of Davutoğlu's neo-Ottoman concept of "strategic depth," without realizing that it was a Faustian pact.

For the sake of Turkey's status as a first-rate regional power-pleasing to their Kemalist-nationalist sensibilities - the secularist elite were prepared to close their eyes to the fact that Islam is the all-encompassing denominator of the project. Back in the fragile early days of 2002-2003 the AKP leader- 
ship wisely grasped the need for the secularist nationalists to be given a slot in the national consensus on Turkey's multi-layered identity. Those days are now over.

Many inherited Weimar officials, Wilhelmstrasse diplomats and top officers of the Reichswehr were likewise not supportive of the Nazis when Hitler came to power. During the crucial early years of the Third Reich (January 1933-January 1938), they were likewise willing to offer their services to his de facto revolutionary project in the name of promoting traditional German national interests and objectives. In early 1938 they were inevitably swept away in a fresh wave of Gleichschaltung, heralded by the removal of General von Blomberg and foreign minister Konstantin von Neurath.

In 2010-2011 Turkey's Islamists were finally able to do the same to the Kemalist civil service and army cadres. Their replacements, steeped in Islamism and neo-Ottomanism, are being groomed at the lower levels of the hierarchy. Their dilemma, for many decades before Erdogan, had been to resist the lure of irredentism abroad, and at home to turn Islam into a matter of personal choice separate from the state and distinct from the society. It could not be done.

The Army Humiliated - The arrest in early 2011 of over a hundred active-duty military officers as part of an investigation into an alleged plot to topple the government was the final chapter in the demise of the Turkish army as a relevant political factor. The arrests brought to 196 the number of active and retired officers who were accused of involvement in the so-called Sledgehammer Plot dating back to 2003. In February 2011, prosecutors requested that 163 of the accused remain under arrest - most of them active duty senior ranks - on a dubious legal pretext. The suspects include the former commanders of the Turkish navy and air force.

This was a massive purge in preparation for the largest show trial ever in the non-Communist world. The charges, too, were worthy of Moscow 1937. The Sledgehammer plot, the government alleged, was to have included bombings of historic mosques in Istanbul, an attack on a museum, and the provocation of military tensions with neighboring Greece including aerial attacks on Greek islands. Such acts of terrorism and outright military aggression were supposedly designed to plunge Turkey into utter chaos and provide an opportunity for the military to step in and remove the AKP-controlled government from power.

The Sledgehammer was connected to the reported Ergenekon conspiracy, supposedly the Mother of All Plots, the mega-conspiracy in which the "Deep State" - a shadowy coalition of senior military officers, the intelligence services, the judiciary, and organized crime - planned terrorist attacks to 
foment unrest leading to a military takeover. The claims about these supposed conspirators defy logic. Arch-secular nationalists, the prosecutors said, had been in bed with the Maoist PKK, the extreme-left Revolutionary People's Liberation Party, the Islamist Hizbullah and Milli Görüp, the ultranationalist Turkish Revenge Brigades, the Turkish Workers' and Peasants' Liberation Army, and the Marxist-Leninist Communist Party.

Details of the "Sledgehammer" emerged after an anonymous source delivered a suitcase full of supposedly secret military documents to a newspaper reporter in January 2010. Prime Minister Erdogan and other AKP leaders have openly lent credibility to the charges. There were countless inconsistencies in the accusations, however. To take one example, dozens of entities - hospitals, NGOs, companies, and even military units - were referred to by names or acronyms which they acquired many years after 2003, in some cases as late as August 2009. The military has strenuously denied the allegations, claiming that the documents were forged, and insisting that the scenarios were part of a hypothetical war game that took place at a military training seminar. "The Turkish Armed Forces, which have especially avoided any actions that could be seen as interfering with the ongoing judicial process, have explained through repeated statements, in no uncertain terms, what the seminars were, how they were carried out, what they involved and who participated under what orders," the April 6, 2011, General Staff statement said.

The Sledgehammer case was not a "case" at all; it was a successful ateempt by the AKP regime to neutralize Turkey's once-powerful military once and for all. The government's specific objective was to discredit the officer corps and thus facilitate the abolition of the Army's traditional role as the guardian of the country's secular political system. According to Dani Rodrik of Harvard University - whose father-in-law, retired four-star general Cetin Dogan, is one of the defendants - we were witnessing machinations in the guise of the judicial process aimed at achieving political advantage instead of justice. The result is that "Turkey's relevance as a democratic beacon for the Middle East" has been undermined.

Turkey's legal system has always been viewed as something opaque, arbitrary, and capricious - another weapon to be used by the powerful against their enemies, not a source of justice for ordinary people. Its continued misuse is an issue which is a matter of legitimate concern, if we are to take seriously President Obama's rhetoric about Turkey as the essential bridge between the East and the West..

Turkish Services to the Ummah - The fact that Turkey is no longer a Western "ally" is still strenuously denied in Washington; but we were remin- 
ded of the real state of affairs on March 9, 2010, when Saudi King Abdullah presented Turkish Prime Minister Recep Tayyip Erdogan with the Wahhabist kingdom's most prestigious prize for his “services to Islam.” Erdogan earned the King Faisal Prize for having "rendered outstanding service to Islam by defending the causes of the Islamic nation."

Turkey under Erdogan's neo-Islamist AKP has rendered a host of other services to "the Islamic nation.” In August 2008 Ankara welcomed Mahmoud Ahmadinejad for a formal state visit, and last year it announced that it would not join any sanctions aimed at preventing Iran from acquiring nuclear weapons. In the same spirit the AKP government repeatedly hosted Sudan's President Omer Hassan al-Bashir, who is accused by the International Criminal Court (ICC) of genocide against non-Muslims. Turkey is currently favoring the replacement of Bashar al-Assad in Syria, ostensibly in the name of democracy, but fully cognizant that the beneficiary of the regime change would be the Muslim Brotherhood.

Simultaneous pressure to conform to Islam at home has gathered pace over the past seven years, and is now relentless. Turkish businessmen will tell you privately that sipping a glass of raki in public may hurt their chances of landing government contracts; but it helps if their wives and daughters wear the hijab.

Changing Gears on Europe - Ankara's continuing bid to join the European Union is running parallel with its openly neo-Ottoman policy of re-establishing an autonomous sphere of influence in the Balkans and in the former Soviet Central Asian republics. Turkey's EU candidacy is still on the agenda, but the character of the issue has evolved since Erdogan came to power in 2002.

When the government in Ankara started the process by signing an Association agreement with the EEC (as it was then) in 1963, its goal was to make Turkey more "European." This had been the objective of subsequent atempts at Euro-integration by other neo-Kemalist governments prior to Erdogan's victory, notably those of Turgut Ozal and Tansu Ciller in the 1990 s. The secularists hoped to present Turkey's “European vocation” as an attarctive domestic alternative to the growing influence of political Islam, and at the same time to use the threat of Islamism as a means of obtaining political and economic concessions and specific timetables from Brussels. Erdogan and his personal friend and political ally Abdullah Gul, Turkey's president, still want the membership, but their motives are vastly different. Far from seeking to make Turkey more European, they want to make Europe more Turkish - many German cities are well on the way - and more Islamic, thus reversing the setback of 1683 without firing a shot. 
Nevertheless, the Western media and politicians remain infatuated with the twin myth of Turkey's "Islamic democracy." Sensing a mix of Western weakness and wishful thinking, Prime Minister Erdogan asserted a year ago that the tables have been turned: in the decades ahead, Europe will need Turkey more than Turkey needs Europe. "European labor markets and social-security systems are comatose," he declared, and "European societies are near geriatric," in contrast to Turkey which is "bursting with the vigor that the EU so badly needs":

Our European friends should realize that Turkey-EU relations are fast approaching a turning point... Turkey is a regional player, an international actor with an expanding range of soft power and a resilient, sizable economy. And yet, the fact that it can withstand being rebuffed should not become reason for Turkey's exclusion. Sometimes I wonder if Turkey's power is an impediment to its accession to the Union. If so, one has to question Europe's strategic calculations ... We are no more a country that would wait at the EU's door like a docile supplicant. Some claim that Turkey has no real alternative to Europe ... However, the opposite is just as valid. Europe has no real alternative to Turkey. Especially in a global order where the balance of power is shifting, the EU needs Turkey to become an ever stronger, richer, more inclusive, and more secure Union. I hope it will not be too late before our European friends discover this fact.

Too late for what exactly? - one may ask. Erdogan's implied threat is that Turkey would turn against "Europe" if it is not admitted into the EU, which is in itself an eloquent argument against admission. No responsible family would unlock the door to an uninvited guest with a long criminal record who threatens unpleasantness if he is not admitted. Fortunately, leading EU countries seem to realize that "Europe" with Turkey in its ranks would be weaker, poorer, and infinitely less safe.

Hostility to Israel - The cooling of traditionally strong relations between Turkey and Israel started with Erdogan's sudden and harsh burst of anti-Israeli rhetoric at Davos three years ago, followed by barring Israel from annual military exercises on Turkey's soil. At the same time, to Israel's dismay, Turkey's strident apologia of Hamas became more vehement than anything coming out of Cairo or Amman. (Talking of terrorists, Erdogan has stated, repeatedly, “I do not want to see the word 'Islam' or 'Islamist' in connection with the word 'terrorism'!") The tension reached its peak with the "Gaza Freedom Flotilla” incident in May 2010,

Turkey's "special relationship" with Israel is over, even at the level of symbolic gestures. As the Israeli daily Maariv reported on August 15, 2010, 
"Relations between Israel and Turkey continue to deteriorate: Israel's ambassador to Ankara, Gabi Levi, was the only one not to be invited to the traditional meal that precedes the Ramadan fast, which took place over the weekend in the presence of Turkish Prime Minister Recep Tayyip Erdogan and senior officials of his Justice and Development Party. All of the other ambassadors were invited."

Israel's defense and security community is in agreement that Turkey was moving toward becoming a radical and nuclear Islamic state. Officials and leading analysts assert that Erdogan was rapidly dismantling the secular Turkish state and turning Turkey into another Iran - a radical Muslim state soon to be armed with nuclear weapons. "There could be a deep strategic change," Amos Gilad, a senior Defense Ministry official, says. The Israelis are particularly concerned by Erdogan's success in intimidating the oncepowerful Turkish military. They point out that Turkey has launched plans to build at least two nuclear reactors and produce enriched uranium. Israeli analysts add that under Erdogan Turkey could acquire weapons technology under the cover of a civilian nuclear program. "If there is not a change in personality, then Turkey will become Iran No. 2," former National Security Council director Uzi Dayan says.

The Neo-Ottoman Strategy in the Balkans - Modern Turkey's Balkan strategy conforms to the old paradigm of the Green Corridor. This is a geopolitical concept with two meanings. It denotes the Islamists' goal of creating a contiguous chain of Muslim-dominated polities from Istanbul in the southeast to northwestern Bosnia, a mere 120 miles from Austria. It also denotes the process of increasing ethno-religious assertiveness among the Muslim communities along that route. That process entails four key elements: (1) Expanding the area of those communities' demographic dominance; (2) Establishing and/or expanding various entities under Muslim political control with actual or potential claim to sovereign statehood; (3) Enhancing the dominant community's Islamic character and identity within those entities, with the parallel decrease of presence and power of non-Muslim groups; and (4) Prompting Muslim communities' ambitions for ever bolder designs in the future, even at the risk of conflict with their non-Muslim neighbors. Understanding this neo-Otoman strategic concept par excellence is essential to a comprehensive understanding of the motives, actions, and emerging expectations of different actors in the Yugoslav wars of 1991-1999 and their aftermath.

Political, cultural, religious and demographic trends among Muslim communities in the Balkans strongly suggest that the Green Corridor is taking shape, either deliberately or spontaneously. Nevertheless, many Western academic experts and media commentators (especially in the English-spea- 
king world) have shown the tendency to be a priori dismissive of any suggestion that a long-term Islamic geopolitical design exists in the Balkans, let alone that it is being deliberately and systematically pursued. The notion of the Green Corridor was thus criticized as a product of Serbian propaganda with "Islamophobic" overtones, although its most authoritative proponents in recent years have been institutions and experts (British, Italian, American, Israeli etc.) with no ethnic or personal axe to grind in the Balkan imbroglio.

The Bosnian war was still raging when Sir Alfred Sherman, former advisor to Prime Minister Margaret Thatcher and co-founder of the Centre for Policy Studies, warned that the Muslims' objective was "to create a 'Green Corridor' from Bosnia through the Sanjak to Kosovo" that would separate Serbia from Montenegro. Western powers are "in effect fostering this Islamistan," Sherman warned, and developing "close working relations with Iran, whose rulers are keen to establish a European base for their politico-religious activities." In addition, "Washington is keen on involving its NATO ally Turkey, which has been moving away from Ataturk's secularist and Western stance back to a more Ottomanist, pan-Muslim orientation, and is actively helping the Muslim forces."

Sherman's 1994 diagnosis proved to be prescient. A decade later it was echoed by Col. Shaul Shay of BESA Center at Bar-Ilan University. He noted that "the Balkans serve as a forefront on European soil for Islamic terror organizations, which exploit this area to promote their activities in Western Europe, and other focal points worldwide." His conclusions regarding the Green Corridor are disquieting: "[T]he establishment of an independent Islamic territory including Bosnia, Kosovo and Albania... is one of the most prominent achievements of Islam since the siege of Vienna in 1683. Islamic penetration into Europe through the Balkans is one of the main achievements of Islam in the twentieth century." Shay's account shows how the Bosnian war provided the historical opportunity for radical Islam to penetrate the Balkans at a time when the Muslim world came to the aid of the Muslims. The Jihadist operational and organizational infrastructures were thus established.

John R. Schindler, professor of strategy at the U.S. Naval War College and former National Security Agency analyst and counterintelligence officer, concurs: in his view the Balkans provide the missing piece in the puzzle of al-Qa'ida's transformation from an isolated fighting force into a lethal global threat. Radical Islam played a key role in the Yugoslav conflict, Schindler says: like Afghanistan in the 1980s, Bosnia in the 1990s became a training ground for the mujahidin, leading to blowback of epic proportions.

The Green Corridor paradigm reflects Samuel Huntington's Clash of Civilizations, which used the war in Bosnia and Herzegovina as a paradig- 
matic case of the so called "fault-line wars" between Islam and the rest. During the Bosnian war (1992-1995) Alija Izetbegovic presented a "pluralist" image to the West, but his followers acted in accordance with his primary message. The fruits of their labor - and that of their coreligionists in another half-dozen countries in the region - are visible along a thousand miles' trail through the middle of today's Balkans.

The spread of Islam in the Balkans was "by the sword": it was contingent upon the extent of Ottoman rule and the establishment of political and social institutions based on the teaching of Kuran and the previous seven centuries of Islamic legal and political practice. The line of the attack went from Thrace via Macedonia to Kosovo; through the Sanjak into Bosnia all the way to the Una river, was finally stopped at the Habsburgs’ Military Frontier created in the 16th century. It is noteworthy that the geographic thrust of the Ottoman attack and later colonization of Muslims from other parts of the Empire in the Balkans coincided exactly with the "Green Corridor." The historical record further indicates that Ottoman efforts at Islamization of the local population were more determined, and far more successful, along the "Transverse" axis (Thrace-Macedonia-Kosovo-Sanjak-Bosnia) than in other conquered Christian lands (e.g. in mainland Greece, central Serbia, northern Bulgaria, or Wallachia).

The Ottoman conquest destroyed the materially and culturally rich Christian civilization of Byzantium and its dynamic and creative Slavic offspring in Serbia and Bulgaria. The conquered populations became secondclass citizens (“dhimmis"), whose physical security was predicated upon their abject obedience to the Muslim masters. They were heavily taxed (jizya, or poll tax, and kharaj) and subjected to the practice of devshirme: the annual "blood levy" (introduced in the 1350s) of a fifth of all Christian boys in the conquered lands to be converted to Islam and trained as janissaries. In the collective memory of Balkan Christian nations, five centuries of Turkish conquest and overlordship - with all their consequences, social and political - are carved as an unmitigated disaster. Conversions to Islam, a phenomenon more strongly pronounced along the Green Route than in the central regions of the Empire, contributed to a new stratification of the society under Ottoman rule and a new power balance. People of the same ethno-linguistic community, sharing the same ancestors, thus often evolved into members of two fundamentally opposed social and political groups.

The Christian communities all over the Balkans are in a steep, longterm demographic decline. Fertility rate is below replacement level in every majority-Christian country in the region. The Muslims, by contrast, have the highest birth rates in Europe, with the Albanians topping the chart. On current form it is likely that Muslims will reach a simple majority in the Balkans 
within a generation. Turkey's European foothold on the Straits and in Eastern Thrace is populous (over 11 million), overwhelmingly mono-ethnic (Turkish) and mono-religious (Muslim); the Christian remnant is negligible. There is a rekindled sense of kinship among the growing ranks of Turkish islamists with their Balkan co-religionists and with the old Ottoman domains further west. The re-Islamization and assertiveness of Turkey under Erdogan is essential to the revival of Islam and ethnic self-assertiveness all along the Green Corridor.

Without a strong, solidly supportive anchor at its southeastern end, no Muslim revival in former Ottoman lands along the Green Corridor would be possible. Under the AKP Turkey has become revisionist, potentially irridentist, and detrimental to stability in the Balkans. Far from providing a model of pro-Western "moderate Islam,” Kosovo, Muslim Bosnia, Sanjak, western Macedonia, and southern Bulgaria are already the breeding ground for thousands of young hard-line Islamists. Their dedication is honed in thousands of newly-built, mostly foreign-financed mosques and Islamic centers. The intent was stated by the head of the Islamic establishment in Sarajevo. "The small jihad is now finished ... The Bosnian state is intact. But now we have to fight a bigger, second jihad,” Mustafa Ceric, the Reis-ul-Ulema in BosniaHerzegovina, declared over a decade ago. This statement reflects the inherent dynamism of political Islam.

Far from enhancing peace and regional stability, neo-Ottoman policies pursued by Ankara continue to encourage seven distinct but interconnected trends centered on the Green Corridor:

(a) Pan-Islamic agitation for the completion of an uninterrupted Transverse by linking its as yet unconnected segments.

(b) Destabilization of Bosnia resulting from constant demands for the erosion of constitutional prerogatives rooted in Dayton, leading to the abolition of the Republika Srpska.

(c) Growing separatism among Muslims in the Raska region of Serbia, manifest in the demand for the establishment of an "autonomous" Sanjak region.

(d) Continuing intensification of greater-Albanian aspirations against Macedonia, Montenegro, Greece, and rump-Serbia.

(e) Further religious radicalization and ethnic redefinition of Muslims in Bulgaria, leading to demands for territorial autonomy in the Rhodope region.

(f) Ongoing spread of Islamic agitation, mainly foreign-financed, through a growing network of mosques, Islamic centers, NGOs and "charities" all along the Route. 
(g) Escalation of Turkey's regional ambitions and Ankara's quiet encouragement of all of the above trends and phenomena.

In all cases the immediate bill will be paid by the people of the Balkans, but long-term costs of the Green Corridor will haunt many Western policy-makers for decades to come.

The Ottoman Legacy - Washington's stubborn denial of Turkey's political, cultural and social reality goes hand in hand with an ongoing atempt in some quarters of the Western academia and mainstream media to rehabilitate the Ottoman Empire, and to present it as a precursor of Europe's contemporary multiethnic, multicultural tolerance and diversity. In reality, four salient features of the Ottoman state were institutionalized discrimination against non-Muslims, total personal insecurity of all its subjects, an unfriendly coexistence of its many races and creeds, and the absence of unifying state ideology. It was a sordid Hobbesian borderland with mosques.

An "Ottoman culture," defined by Constantinople and largely limited to its walls, did eventually emerge through the reluctant mixing of Turkish, Greek, Slavic, Jewish and other Levantine lifestyles and practices, each at its worst. The mix was impermanent, unattractive, and unable to forge identities or to command loyalties.

The Roman Empire could survive a string of cruel, inept or insane emperors because its bureaucratic and military machines were well developed and capable of functioning even when there was confusion at the core. The Ottoman state lacked such mechanisms. Devoid of administrative flair, the Turks used the services of educated Greeks and Jews and awarded them certain privileges. Their safety and long-term status were nevertheless not guaranteed, as witnessed by the hanging of the Greek Orthodox Patriarch on Easter Day 1822.

The Ottoman Empire gave up the ghost right after World War I, but long before that it had little interesting to say, or do, at least measured against the enormous cultural melting pot it had inherited and the splendid opportunities of sitting between the East and West. Not even a prime location at the crossroads of the world could prompt creativity. The degeneracy of the ruling class, blended with Islam's inherent tendency to the closing of the mind, proved insurmountable.

A century later the Turkish Republic is a populous, self-assertive nation-state of over 70 million. Ataturk hoped to impose a strictly secular concept of nationhood, but political Islam has reasserted itself. In any event the Kemalist dream of secularism had never penetrated beyond the military and a narrow stratum of the urban elite. 
Conclusion - The near-impossible task facing Turkey's Westernized intelligentsia before Erdogan had been to break away from the lure of neoimperial irredentism abroad, and at home to reform Islam into a matter of personal choice - in other words, to make Islam separate from the State and distinct from the society. The Kemalist edifice, uneasily perched atop the simmering Islamic volcano, had always been unstable. Today it is an empty shell. Today's Turkey is a regional power of considerable importance which bases its strategy on the concept of neo-Ottomanism, while denying its existence. Neo-Ottoman Turkey's interests and aspirations no longer coincide with those of the United States or Europe, and they are diametrically opposed to the interests of the traditionally Orthodox Christian nations in the Balkans. 